\title{
MANAJEMEN UNIT USAHA PESANTREN
}

\author{
Inayah Swasti Ratih ${ }^{1}$ \\ Maidah Sufiani2 \\ 12 Program Studi Manajemen Bisnis Syariah, Sekolah Tinggi Ekonomi dan Bisnis Islam \\ Email: risetinayah@gmail.com¹; maidah.sufiani@stebibama.ac.id ${ }^{2}$
}

\begin{abstract}
Introduction: The purpose of this study is to find and describe the independence of pesantren through pesantren business units in the form of tofu factories and analyze the development of pesantren independence capital, analyze factors supporting the formation of pesantren independence and analyze obstacles to the formation of pesantren independence.

Methods: The research method used isqualitative metode using primary data sources through interviews about data and information related to research. The economic development of pesantren through the tofu factory business unit established in 2013 that gets a loan of funds from pesantren, with profits obtained for the initial return on capital. Result: Marketing through offline and online where santri also plays a role in the economic development of pesantren which is also currently acting as a transaction. Its financial statements are conducted weekly and monthly collected to benhara Koppontren. The management of pesantrren business units in the form of factories know must be developed by improving its marketing model which not only has a target market in its own pesantren but with other pesantren and the general public.
\end{abstract}

Keywords: management business, pondok pesantren, factory of pesantren

\section{PENDAHULUAN}

Pesantren sebagai Lembaga Pendidikan tertua di Indonesia merupakan wabah tempat untuk berlangsungnya pembelajaran khusus tentang kajian keislaman yang memiliki sistem yang kompleks dan dinamis. Dalam kegitannya pesantren menjadi satuan pendidikan bukan hanya sebatas tempat menginap santri. Pesantren juga merupakan suatu tahanan sistem yang mempunyai unsur yang saling berkaitan, dam memilki tujuan yang jelas yang melibatkan banyak sumber daya Pendidikan guna mencapai tujuan, baik yang bersifat individu ataupun tujuan kelembagaan. Untuk mencapai tujuan tersebut, berlaku kententuan yang mengatur hubungan unsur yang satu dengan yang lainnya. Oleh 
karena itu, pesantren sebagai sebuah satuan pendidikan yang mengkaji disiplin ilmu agama sebagai organisasi pembelajaran yang membutuhkan pengelolaan sumber daya pendidikan termasuk sumber daya belajar ${ }^{1}$. Pesantren dipandang sebagai penjaga moral etik bagi masyarakat sehingga mampu menjadi mediator bagi masyarakat. Lembaga pondok pesantren memainkan peranan penting dalam usaha memberikan Pendidikan bagi bangsa Indonesia, terutama Pendidikan agama. Dari awal mula adanya pesantren hingga saat ini masih terus dapat eksis dan berkembang dalam upaya memberikan pendidikan yang bermutu oleh karenanya diarahkan untuk melihat dengan jelas perkembangan yan terjadi pada dunia pesantren dari awal mulanya hingga saat ini, serta pondok pesantren lembaga pendidikan yang mengayomi masyarakat.

Begitu pula dalam sejarah pondok pesantren sebagai Lembaga Pendidikan yang mempunyai tujuan yang tidak jauh beda dengan Pendidikan agama islam yakni mencapai akhlak yang sempurna atau mendidik budi pekerti dan jiwa, maksud dari mencapai akhlak yang sempurna yakni dapat digambarkan pada terciptanya pribadi muslim yang mencapai indikator iman, taqwa, ta'at menjalankan perintah sang maha kuasa, berakhlak mulia dan dewasa secara jasm ani dan rohani, serta berusaha untuk hidup sesuai dengan ajaran islam. Pesantren dibagi menjadi dua menurut Arifin, yaitu tujuan umum dan tujuan khusus. Pesantren secara umum memiliki tujuan untuk membimbing anak didik agar menjadi manusia yang berprikebadian islam yang sanggup dengan ilmu agamanya menjadi muballigh dalam masyarakat dengan ilmu dan amalnya, sedangkan tujuan khusus dari pesantren adalah mempersiapkan para santri untuk menjadi orang alim dalam ilmu agama yang diajarkan oleh kyai dan mengamalkannnya dalam kehidupan masyarakat ${ }^{2}$. Dalam sejarah Pondok pesantren mula-mula ada kyai yang alim berdiam disuatu tempat lalu berdatangan orang orang untuk mendapatkan bimbingannya adapun sebagian yang ingin bermukim yang ditampung dirumah kyai setelah semakin banyak dibangunlah suatu pondok yang lengkap dengan masjid/musholla dan fasilitas lainnya. Asal usul pesantren terdiri dari 5 unsur yaitu Kyai, santri, masjid, pengajaran dan ilmu ilmu agama sebagai referensi pokok dalam kajian keislaman ${ }^{3}$.

Adapun jumlah santri sejawa timur yang mukim 323.293 santri, yang tidak mukim 241.006 santri, jumlah pesantren sejawa timur sebanyak 4452 pesantren, jawa timur memiliki berbagai jenis pondok pesantren, baik pondok pesantren modern maupun pondok pesantren salafiyah. Pondok pesantren modern adalah system yang dipopulerkan pertama kali oleh pondok pesantren Darussalam Gontor Ponorogo yang kemudian

1 Imam Syafe'i, 'PONDOK PESANTREN: Lembaga Pendidikan Pembentukan Karakter', Al-Tadzkiyyah: Jurnal Pendidikan Islam, 8.1 (2017), 61 <https://doi.org/10.24042/atjpi.v8i1.2097>.

2 Samsul H Nizar, Sejarah Pendidikan Islam (Menelusuri Sejarah Pendidikan Era Rasulullah Sampai Indonesia) (Jakarta: Prenada Media Gorup, 2011).

${ }^{3}$ Dadan Muttaqien, 'Sistem Pendidikan Pondok Pesantren (Sebuah Alternatif Mengatasi Kegagalan Sistem Pendidikan Barat)', JPI FIAI Jurusan Tarbiyah Volume V Tahun IV Agustus 1999, V (1999), 79-87. 
diduplikasikan oleh berbagai pondok pesantren lainnya yang memakai label modern. Pondok pesantren modern biasanya lebih fokus terhadap pelajaran umum, Bahasa, kedisiplinan, kepemimpinan, dan sedikit kurang dengan ngaji kitab kuning. Pondok pesantren salafiyah adalah bentuk asli dari lembaga pesantren, yang didirikan oleh Wali songo, format pondok pesantren adalah system salaf. Salaf berasal dari Bahasa arab salafa yang berasal dari akar kata sama dan beberapa makna dari kata salaf yang berbeda. Pondok pesantren salafiyah masih terpaut dengan program ngaji kitab kuning, dan tidak terlalu focus pada pelajaran umum. Serta pondok pesantren harus mampu berkembang tanpa kehilangan originalitas yang menjadi ciri khas pesantren itu sendiri, usaha mandiri yang dijalankan pesantren harus membawa dampak positif bagi masyarakat pesantren, maka pesantren melakukan pengembangan salah satunya pembentukan unit usaha untuk mengembangkan dan memenuhi kebutuhan ekonomi pondok pesantren. Oleh karena itu pondok pesantren tanpa sepenuhnya bergantung dengan pemerintah, disebabkan unit usaha yang dijalankan oleh pondok pesantren bermanfaat bagi masyarakat sehingga perekonomian pesantren berkembang.

Manajemen adalah perpadan perlaksanaan fugnsi- fungsi perencanaan, pengorganisasian, pelaksanaan (actuiting), dan pengawasan/pengendalian (controlling) untuk mencapai tujuan tertentu dalam dalam waktu tertentu pula. Profesional adalah sebagai ciri ciri kekuatan yang dimilki seseorang berupa keahlian, kompetensi, kerja efesien, keterampilan, kualifaid-pandai, berpengalaman, dan sifat mengagumkan ${ }^{4}$. Dalam konteks SDM, manajemen professional adalah pelaksanaan fungsi-fungsi tersebut dalam pengembangan mutu SDM secara professional. Lawannya adalah manajemen amatiran yang ciri-cirinya bertentangan dengan ciri-ciri manajemen professional dengan begitu manajemen bisnis menerapkan prinsip prinsip islam yang sudah diajarkan oleh Rasulullah SAW.

Prinsip-prinsip etika bisnis yang berlaku dalam kegiatan bisnis yang baik sesungguhnya tidak bisa dilepaskan dari kehidupan kita sebagai manusia, hal ini berarti bahwa prinsip- prinsip etika bisnis terkait erat dengan sistem nilai yang dianut oleh masing- masing masyarakat ${ }^{5}$. Dalam hal ini ternyata system yang berasal dari agama memberi pengaruh yang dominan terhadap prinsip-prinsip etika bisnis pemeluknya, seperti yang telah diajarkan oleh ajaran agama islam, yang dicontohkan oleh Rasulullah SAW, yaitu: Customer Oriented, Tranparansi, Persaingan yang sehat, Fairness. Dengan begitu berbagai unit usaha yang berdiri pada zaman sekarang belum semua melakukan prinsip prinsip berbisnis yang sudah diajarkan oleh Rasulullah, unit usaha yang berdiri dibawah naungan dipondok pesantren sudah pasti akan menerapkan prinsip ala

\footnotetext{
4 George R. Terry, Dasar Dasar 2013 $<$ https://repository.widyatama.ac.id/xmlui/bitstream/handle/123456789/6350/Bab 2.pdf?sequence=11>.

${ }^{5}$ Abdul Mannan and Inayah Swasti Ratih, 'Penerapan Etika Bisnis Islam Dalam Usaha Mikro Mebel/UMKM', IZZI : Jurnal Ekonomi Islam, 1.2 (2021), 133-47.
} 
Rasulullah karna pesantren yang terkenal sebagai tempat pencarian ilmu agama, oleh karena itu unit usaha yang berdiri dipondok pesantren Al Mashduqiah menerapkan prinsip prinsip tersebut untuk kemaslahatan Bersama sehingga tidak merugikan satu sama yang lain. Pendiri unit usaha dilakukan oleh Pondok pesantren Al Mashduqiah. Pada tanggal 28 Juli 1998 berdirilah Pondok pesantren Al Mashduqiah yang mana pondok ini didirikan oleh Dr. KH. Mukhlisin Sa'ad. MA. Dan Nyai. Hj. Zulfa Badri S.Pdi sampai sekarang sehingga pondok pesantren Al Mashduqiah sudah mencapai umur kurang lebih 22 tahun. Pondok Pesantren Al Mashduqiah lahir sebagai upaya parsisipatif dalam mewujudkan cita-cita luhur "mengembalikan kejayaan islam dan kaum muslimin"(Izzul Islam Wal Muslimin). Ia berdiri diatas sebidang tanah wakaf seluas 5,6 ha, dikelurahan Patokan Kraksaan Probolinggo. Suasana lingkungannya masih asri, tenang, aman, dan sejuk sehingga mendukung terciptanya semangat belajar yang tinngi dan memungkinkan pengembangan potensi santri. Pondok pesantren Al Mashduqiah yang terdiri dari santri putra dan santri putri dengan menerapkan Pendidikan umum dan Pendidikan agama secara utuh dan terpadu. Semua pelajar wajib bermukim dalam asrama pesantren dengan mengikuti seluruh disiplin pesantren yang berlaku. Lembaga Pendidikan formal meliputi SMP dan MA Plus (jurusan IPA dan Bahasa) yang dipadukan dengan kurikulum muallimin sebagai mana yang diterapkan di Pondok Pesantren Modern Darussalam Gontor Ponorogo. Pondok Pesantren Al Mashduqiah memiliki jenjang Pendidikan dengan system Halqotul Muallimin Wal Muallimat Al-Islamiyah (HAMIM) yang mana system ini diterapkan khusus santri dengan masa belajar 6 atau 4 tahun. Program Pendidikan pondok pesantren Al Mashuqiah ada 3 yaitu: Intra Kurikuler, ko kurikuler, ekstra kulikuler. Dan mempunyai 5 panca jiwa diantaranya 1). Jiwa Keikhlasan 2). Jiwa Kebebasan 3). Jiwa Berdikari (berdiri diatas kaki sendiri) 4). Jiwa Ukhuwah Islamiyah 5). Jiwa Kebebasan. Dan tidak lupa Pondok Pesantren Al Mashduqiah mempunyai 3 motto yaitu beriman sempurna, berilmu luas, beramal sendiri.

Pondok Pesantren Al Mashduqiah juga mempunyai keunggulan yaitu pembelajaran Bahasa Asing (Arab atau Inggris) merupakan salah satu program unggul pesantren. Kedua Bahasa tersebut diajarkan dan digunakan dalam kelas serta menjadi Bahasa percakapan sehari hari. Pembelajaran Bahasa Asing secara intensif ini dimaksudkan agar para santri mampu menelaah buku-buku berbahasa asing dan sebagai perkenalan untuk meneruskan studi diluar negeri. Selain itu juga, Al mashduqiah melakukan pengembangan dengan pembentukan unit usaha koppontren (Koprasi Pondok Pesantren) untuk mengembangkan ekonomi pesantren melalui unit unit usaha diantaranya, USPS (Unit Simpan Pinjam Syariah), pabrik roti, toko putri, grosir, MJ (Murah Jaya), toko putra, konveksi, wartel, dan juga pabrik tahu yang sedang berkembang pertahunnya karena tahu sebagai sumber bahan pokok. Tahu adalah makanan kaya gizi yang merupakan kebutuhan pokok bagi warga pesantren dan masyarakat sekitarnya. Tujuan penelitian ini untuk mengeskplorasikan dan mendeskripsikan kemandirian santri 
dipondok pesantren, menganalisis perkembangan modal kemandirian pondok pesantren, menganalisis faktor pendukung pembentukan kemandirian pesantren serta menganalisis penghambat pembentukan kemandirian pesantren.

\section{TINJAUAN PUSTAKA}

Menurut Qomar (2008) dalam Reginald (2014) pondok pesantren berasal dari dua kata yaitu pondok dan pesantren. Pondok berasal dari bahasa Arab yaitu "funduq" yaitu tempat menginap atau disebut juga dengan asrama. Pesantren berasal dari kata santri yang diimbuhi awalan pe dan akhiran -an yang artinya para penuntut ilmu ${ }^{6}$. Pondok juga bermakna satu tempat yang tersedia untuk santri dalam menemani pelajaran-pelajaran agama islam sekaligus tempat berkumpul dan tempat tinggal para santri ${ }^{7}$. Pondok pesantren secara teknik merupakan suatu tempat yang dihuni oleh para santri. Hal ini menunjukkan makna penting dari ciri-ciri pondok pesantren sebagai sebuah lingkungan pendidikan yang terintegrasi. Sistem pendidikan pondok pesantren sebatulnya sama dengan adanya sebuah bangunan beranda yang disitu seseorang dapat mengambil pengamalan secara integral ${ }^{8}$.

Pondok pesantren memiliki beberapa jenis diantara pondok pesantren modern, salafiyah. Yang dimaksud dengan pondok pespntren modern adalah pesantren yang menganut system Pendidikan yang diadopsi dari system Pendidikan modern dan materi yang dipelajari merupakan kombinasi antara ilmu agama dan ilmu umum . pesantren modern sangat memperhatikan terhadap mengembangkan bakat dan minat santri sehingga santri bisa mengekplor diri sesuai dengan bakat dan minat masing-masing9. Sedangkan secara terminology sosisologis pondok pesantren salaf adalah sebuah pesantren yang lebih memfokuskan kepada kitab kitab kuning sehingga ilmu umum hanya sedikit pemberitahuannya. pesantren salafi ditambah dengan lembaga sekolah (madrasah, SMU atau kejuruan) yang merupakan karakteristik pembaharuan dan modernisasi dalam pendidikan Islam di pesantren. Meskipun demikian, pesantren tersebut tidak menghilangkan sistem pembelajaran yang asli yaitu sistem sorogan, bandungan, dan wetonan yang dilakukan oleh kyai atau ustadz ${ }^{10}$.

\footnotetext{
${ }^{6}$ Jurnal Darul and IImi Vol, 'DINAMIKA PERKEMBANGAN PONDOK PESANTREN DI INDONESIA Oleh: Zulhimma 1', 01.02 (2013), 165-81.

7 Abdul Basit and Tika Widiastuti, 'MODEL PEMBERDAYAAN DAN KEMANDIRIAN EKONOMI DI PONDOK PESANTREN MAMBA'US SHOLIHIN GRESIK', Jurnal Ekonomi Syariah Teori Dan Terapan, 6.4 (2016), 1-23.

${ }^{8}$ Samsul Bahri, 'Pemikiran KH. Abdurrahman Wahid Tentang Sistem Pendidikan Pesantren', EDUGAMA: Jurnal Kependidikan Dan Sosial Keagamaan, 4.1 (2018), 101-36.

${ }^{9}$ MRP Sukma, 'Lembaga Pendidikan Pembentukan Karakter', Al-Tadzkiyyah: Jurnal Pendidikan Islam, 8 (2015), 85-103.

${ }^{10}$ E Prasidjo, S., \& Al, Profil Pesantren", Dalam Abudin Nata (Editor), Sejarah Pertumbuhan Dan Perkembangan Lembaga-Lembaga Pendidikan Islam Di Indonesia. (Jakarta: Grasindo, 2001).
} 
Dalam sebuah pondok pesantren akan memiliki manajemen keuangan menurut Masysarah dikutip oleh Sulistyorini menjelaskan bahwa manajemen keuangan adalah suatu proses melakukan kegiatan mengatur keuangan dengan menggerakkan tenaga orang lain. kegiatan ini dapat dimulai dari perencanaan, pengorganisasian, pelaksanaan, sampai pengawasan. Dalam manajemen keuangan dipesantren tersebut dimulai dengan perencanaan anggaran sampai dengan pengawasan dan tanggung jawaban keuangan, manajemen keuangan dilakukan dengan mandiri. Manajemen adalah proses planning, organizing, leading, dan controlling dengan menggunakan sumber daya perusahaan untuk memenuhi tujuan performa perusahaan ${ }^{11}$. Manajemen merupakan proses bekerja dengan orang dan sumber daya untuk memenuhi tujuan organisasi ${ }^{12}$.

Menurut Hetherington dalam Spencer dan Kass (1976, Rahmah 2004; Retnowati 2008) menyatakan bahwa kemandirian ditunjukkan dengan adanya kemampuan untuk mengambil insiatif, kemampuan untuk mengatasi masalah, penuh ketekunan, memperoleh kepuasan dari usahanya serta keinginanan mengerjakan sesuatu tanpa bantuan orang lain ${ }^{13}$. Kemandirian adalah suatu kondisi dimana seseorang tak tergantung pada suatu otoritas tertentu. Kemandirian adalah kemampuan untuk mengurus dirinya sendiri dan menyelesaikan secara mandiri. Dalam istilah psikologi, kemandirian diartikan sebagai " Independen " yang diartikan sebagai suatu kondisi dimana seseorang tidak bergantung pada orang lain dalam menentukan keputusan, menentukan pilihan yang ditopang dengan rasa percaya diri yang kuat ${ }^{14}$.

Kegiatan produksi tidak akan terwujud dan terlaksana tanpa adanya alat atau benda yang digunakan untuk memproduksi suatu barang. Jadi diperlukan adanya faktorfaktor produksi untuk menciptakan atau menghasilkan benda atau jasa15. Dengan produksi tahu yang dikelola oleh pabrik tahu Al Mashduqiah menciptakan kemandirian pondok serta mengembangkan perekonomian pesantren.

Manajemen ekonomi mandiri ini telah banyak terjadi pada beberapa Pondok Pesantren yang berkembang dan maju di Indonesia. Dengan cara memprioritaskan implementeasi manajemen ekonomi yang profesional, dapat memandirikan sistem ekonomi itu sendiri sehingga berimplikasi terhadap perkembangan layanan pendidikan yang disediakan. Hal tersebut disebabkan oleh implikasi manajemen yang baik terhadap sistem perekonomian Pondok Pesantren, kemudian mengalir dari sistem perekonomian

\footnotetext{
${ }^{11}$ George R. Terry.

${ }^{12}$ T. Pramintasari and I. Fatmawati, 'Pengaruh Keyakinan Religius, Peran Sertifikasi Halal, Paparan Informasi, Dan Alasan Kesehatan Terhadap Kesadaran Masyarakat Pada Produk Makanan Halal', Jurnal Manajemen Bisnis, 8.1 (2017), 1-33.

${ }^{13}$ Pondok Pesantren and Nurrohman Al-burhany Purwakarta, 'Jurnal Comm-Edu', 20, 2019, 193-201.

${ }^{14}$ Basit and Widiastuti.

${ }^{15}$ Muhammad Aminul Khoiris Salam, 'Perilaku Produksi Di Tengah Krisis Global Akibat Pandemi Covid-19 Dan Memanfaatkan Media Online Facebook Sebagai Alternatif Pasar', Ekonomi, Manajemen Dan Akuntansi ISSN: 1979-9888, 2020, 1-21 <http://eprints.umsida.ac.id/id/eprint/6834>.
} 
yang baik berimplikasi baik terhadap berdirinya usaha-usaha baru di lingkungan Pondok Pesantren, kemudian dengan banyaknya usaha tersebut maka berkontribusi besar terhadap banyaknya pendapatan usaha Pondok Pesantren yang kemudian dapat memenuhi kebutuhan layanan Pendidikan.

\section{METODE PENELITIAN}

Metode penelitian ini menggunakan pendekatan kualitatif dimana pada penelitian ini dilakukan untuk mengesplorasi tentang perkembangan ekonomi pesantren melalui unit usaha pabrik tahu dipondok pesantren Al Mashduqiah. Untuk itu metode kualitatif yang berbasis primer dari interview mengenai data dan informasi yang terkait dengan penelitian. Objek penelitian yang digunakan adalah manajemen pengelolaan pabrik tahu dan kemandirian ekonomi pesantren selain itu, pengumpulan data dilakukan dengan cara mengumpulkan data-data terkait dengan penelitian berasal dari data primer ataupun data sekunder. Observasi pada penelitian ini digunakan untuk mengamati secara langsung kondisi dan kegiatan yang ada dipabrik tahu pondok pesantren Al-Mashduqiah observasi ini dilakukan untuk melengkapi data hasil in depth interview.

Teknik pengumpulan data dalam penelitian tersebut menggunakan wawancara, wawancara adalah pola khusus dari interaksi dimulai secara lisan untuk tujuan tertentu, dan difokuskan pada daerah konten yang spesifik, dengan proses eliminasi dari bahanbahan yang tidak ada hubungannya secara berkelanjutan. Ditinjau dari segi pelaksanaannya, wawancara dibagi menjadi 3 jenis yaitu: wawancara bebas, wawancara terpimpin, wawancara bebas terpimpin, wawancara merupakan salah satu cara pengumpulan data, sedangkan pengumpulan data antara lain, metode pengamatan secara langsung, metode dengan menggunakan pertanyaan serta menggunakan metode khusus. Adapun informasi untuk pelengkapi data-data primer informasi yang digunakan adalah informasi kumpulan pesan atau yang berupa koleksi data dan fakta sering kali dinamakan informasi statistic. Serta dalam sebuah penelitian juga melakukan pengecekan data melalui pengujian keabhasan data. Dalam penelitian ini wawancara dilakukan dengan cara observasi ataupun interview langsung kepada Arnikuma yang menjabat sebagai ketua pabrik tahu.

\section{HASIL DAN PEMBAHASAN}

\section{A. Profil Unit Usaha Pabrik Tahu}

Pondok Pesantren Al Mashduqiah berdiri pada tanggal 28 Juli 1998 yang didirikan oleh KH. Mukhlisin Sa'ad MA dan Nyai. Hj. Zulfa Badri S. Pdi, diatas tanah waqof Kyai Badri Mashduqi dengan keluasan tanah 5,6 ha yang terletak di Jln. Ir. H. Juanda 370 Patokan Kraksaan Probolinggo Jawa Timur yang sampai saat ini terus berkembangan ekonominya 
melalui unit unit yang didirikan oleh pengasuh untuk kemandirian pondok pesantren termasuk salah satunya yaitu pabrik tahu.

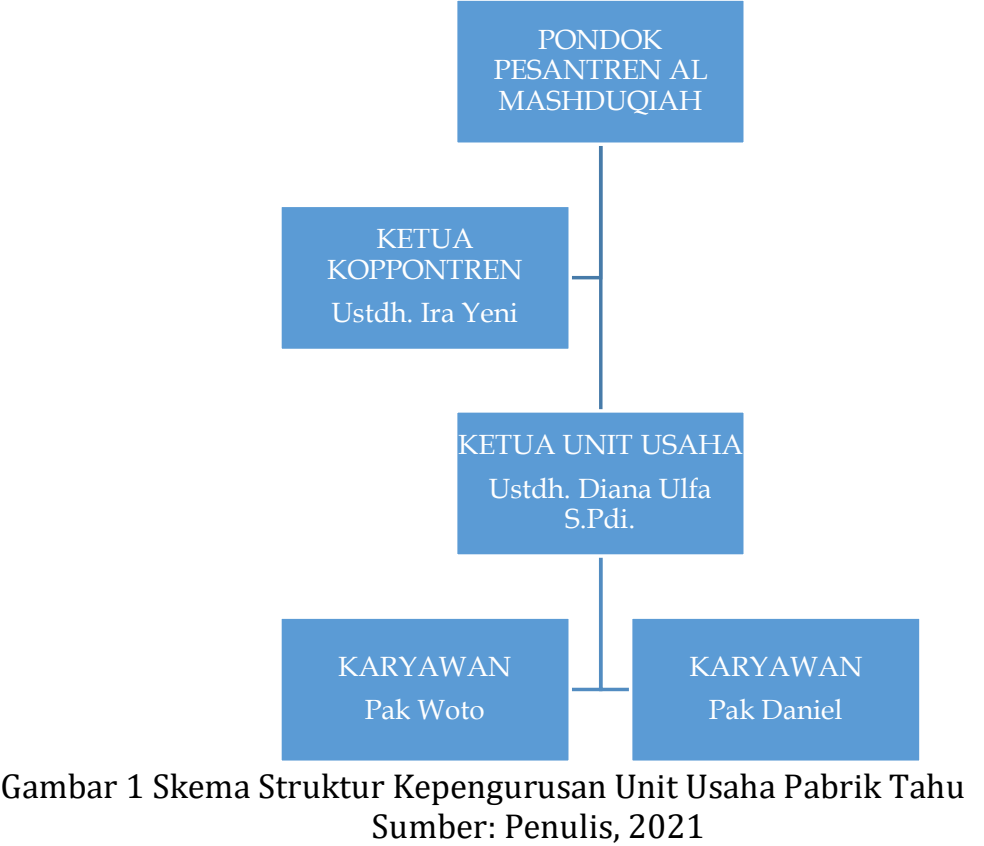

Pabrik Tahu yang berdiri pada tahun 2013 yang diketuai oleh Ustadzh Diana Ulfa S.Pdi. serta pabrik tahu juga dikelola oleh Pak Woto dan Daniel sebagai karyawan pabrik tahu sampai saat ini dengan kelincahan mereka membuat tahu yang lembut sehingga konsumen banyak yang tertarik dengan tahu yang dikelola oleh unit pabrik tahu $\mathrm{Al}$ Mashduqiah. Dengan banyaknya konsumen profit yang didapatkan setiap harinya mampu mengembalikan modal kepada peminjam dana yang mana pondok pesantren $\mathrm{Al}$ Mashduqiah yang menjadi peminjam dana untuk pembangunan pabrik tahu sebesar Rp.20.000.000, sehingga dengan begitu unit usaha pabrik tahu yang sudah 8 tahun beroperasi akhirnya bisa mengembalikan kepada peminjam dana selama satu tahun dan saat ini bisa berdiri sendiri.

\section{B. Manajemen Produksi}

Disetiap industri membutuhkan stategi pengelola yang amanah agar dapat berkembang dengan baik, pengelola pabrik tahu tidak hanya karyawan yang berperan didalam industri melainkan ketua pengawasan dari Koppontren dan Kepala Unit usaha yang sudah mendapatkan amanah langsung dari pengasuh pondok pesantren sehingga kinerja Unit usaha mencapai efektifitas dan efisiensi. Kepemimpinan yang ideal memiliki dua sifat dasar, kuat (mampu) dan amanah. Sebagaimana yanga sudah tertera dalam firman Allah SWT:

"Sesungguhnya orang yang paling baik yang kamu ambil untuk bekerja (pada kita) dan amanah."(QS Al-Qashash 28)

Tidak hanya itu pengasuh pesantren juga ikut berpartisipasi dengan berkembangnya unit usaha meskipun tidak langsung turun tangan tapi pengasuh membantu memasarkan produk dan memantau secara online yang mana didalam sebuah Koppontren terdapat grup disitulah permasalahan dan apa yang terjadi dilaporkan sehingga pengasuh 
mengetahui kinerja karyawan dan bagaimana mengelolaan keungannya. Yang mana yang sudah disampaikan oleh ketua Koppotren sebagai berikut:

"jelas berpartisipasi dalam penjualannya dan keuangannya, tidak langsung

turun tangan cuman membantu memasarkannya dan memantau digrup"

Pengasuh pesantren melalukan pengawasan terhadap semua aspek dari keuangan, kinerja karyawan, perkembangan SDM serta evaluasi terhadap keuntungan setiap bulan Bersama Ketua Koppontren dan Ketua unit, sebagai pemimpin mempunyai tanggung jawab atas kepemimpinan. Sebagimana yang diriwayatkan oleh Bukhori pada kalimat seperti dibawah ini:

"Setiap dari kalian adalah pemimpin dan tiap pemimpin akan dimintai pertanggung jawabannya" H.R Bukhori

Tidak hanya pengasuh ataupun pengurus yang mempunyai tanggung jawab, karyawan pun juga memiliki tanggung jawab dalam pengelolaan produk tahu pertanggung jawaban terhadap bahan yang akan dikelola, meskipun proses pengelolaannya mudah tidak semua orang mampu membuat tahu, bila diilustrasikan dalam sebuah flowchart adalah sebagai berikut:

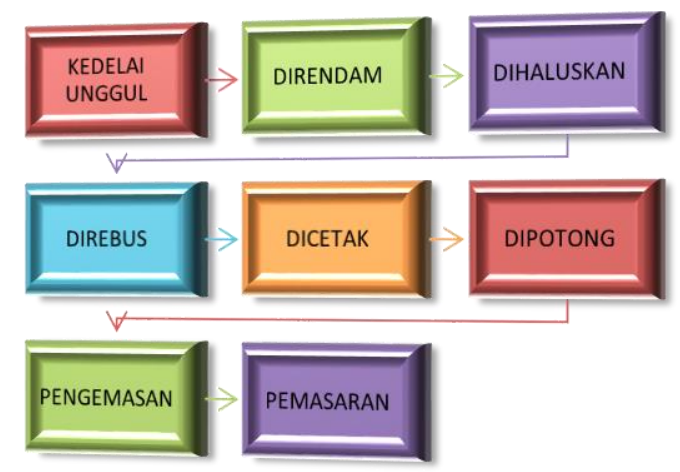

Gambar. 2 Proses Pengelolaan Produk Tahu Sumber: Penulis, 2021

Berdasarkan Skema diatas merupakan urutan bagaimana cara mengelola tahu yang baik, tahu adalah makanan padat dari kedelai yang direndam selama 4 jam lalu dihaluskan setelah itu direbus dan dicetak dari sari kedelai dan hal tersebut memiliki proses produksi untuk menjadi tahu yang berkualitas, untuk penanganan limbah kedelai ketua unit menjual ampas kedelai kepada tetangga yang membutuhkan ampas tersebut untuk diberikan kepada sapi. Maka dari itu Ketua unit (kanit) tidak sembarangan mengambil biji kacang kedelai, dengan begitu Ketua unit (kanit) hanya memproduksi biji kedelai yang sudah terpercaya ditoko Nova dan di toko Hj Khom yang sudah terjamin bersih, berkualitas, dan harga yang terjangkau sehingga pemasarannya cukup stabil dan memuaskan para konsumen. Pemasaran tahu dilakukan secara online dan offline, produk yang dipasarkan secara offline yaitu kepada Unit Unit usaha Pondok Pesantren yang membutuhkan produk tersebut seperti kantin putri dan putra dan juga dapur pondok untuk dikonsumsi oleh para santriwan-santriwati dan juga para warga yang bermukim 
dipondok pesantren, tidak hanya dari Pondok Al Mashduqiah saja yang memproduksi melainkan Pondok Pesantren lainnya, warga sekitar pondok, walisantri Al Mashduqiah juga mengkonsumsi produk tahu, pemasaran yang secara online memanfaatkan social media seperti facebook, whatapps yang mana mayoritas masyarakat menggunakan aplikasi tersebut.

\section{Keuangan Pabrik Tahu}

Berkembangnya ekonomi pesantren setiap unit usaha terlibat terutama pabrik tahu yang setiap bulannya menyisihkan sebagian hasil profitnya sebesar $20 \%$ kepada Pondok melalui keuangan pesantren. Dalam laporan keuangan yang dilakukan unit usaha dibagi menjadi 2 bagian yaitu:

1. laporan perminggu untuk mengetahui kredit debit selama seminggu dengan sistem manual yang dilaporkan kepada keuangan Koppontren(Koprasi Pondok Pesantren).

2. laporan perbulanan yang dilaporkan kepada ketua Kopontren dengan melalui sistem accurate.

Data tersebut menunjukkan adanya ketertiban dalam laporan keuangan unit usaha pabrik tahu. Agar informasi laporan keuangan dapat dipercaya maka informasi tersebut harus diuji oleh pihak pengelola keuangan yang bersikap adil, independen dan obyaktif sebagaimana dalam QS. An-Nisa':135

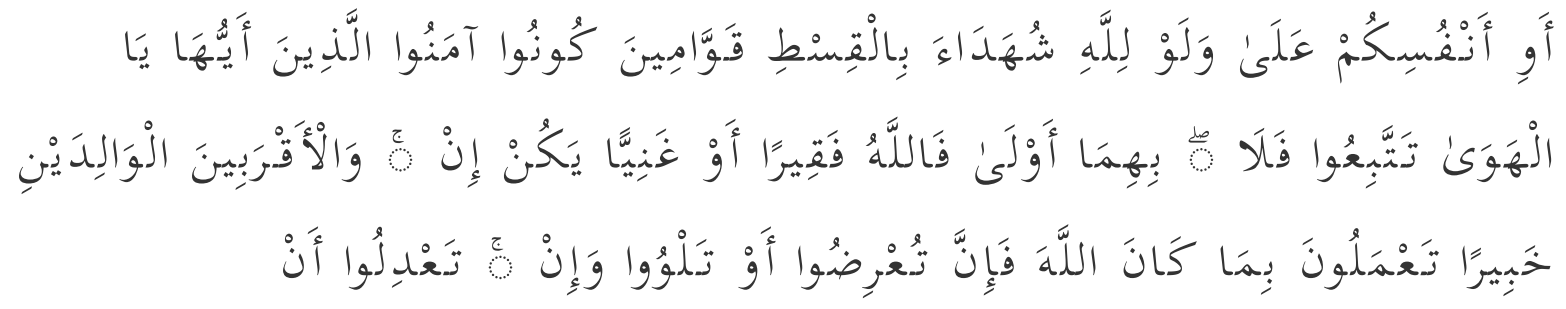

Artinya: wahai orang-orang yang beriman! Jadilah kamu penegak keadilan,menjadi saksi karena Allah, walaupun terhadap dirimu sendiri atau terhadap ibu bapak dan kaum kerabatmu. Jika dia (yang terdakwa) kaya ataupun miskin, maka Allah lebih tau kemashlahatan (kebaikannya). Maka janganlah kamu mengikuti hawa nafsu karena karena ingin menyimpang dari kebenaran. Dan jika kamu memutarbalikkan (kata-kata) atau enggan menjadi saksi, maka ketauhilah Allah mahateliti terhadap segala apa yang kamu kerjakan.

Ayat ini menegaskan tentang kualitas dari persaksian yang obyektif dan independen. Dimana menurut tafsir, keadilan adalah sistem kehidupan yang tidak dipertentangkan lagi. Dari itu, wahai orang-orang yang patuh dan tunduk kepada Allah dan seruan rasul-Nya, biasakanlah dirimu dan orang lain--dalam upaya mematuhi prinsip keadilan--untuk selalu tunduk kepada keadilan. Berbuat adillah terhadap orang-orang yang teraniaya. Jadilah kalian semua penegak keadilan, bukan karena menyukai orang kaya atau mengasihi orang miskin. Karena Allahlah yang menjadikan seseorang kaya dan miskin, dan Dia lebih tahu kemaslahatannya. Sesungguhnya hawa nafsu itu telah 
menyimpang dari kebenaran, maka janganlah kalian mengikutinya, supaya kalian dapat berlaku adil. Jika kalian bepaling atau enggan menegakkan keadilan, maka sesungguhnya Allah Maha Mengetahui apa yang kalian kerjakan dan akan memberi balasannya. Yang baik akan dibalas dengan kebaikan dan yang buruk akan dibalas dengan keburukan pula.

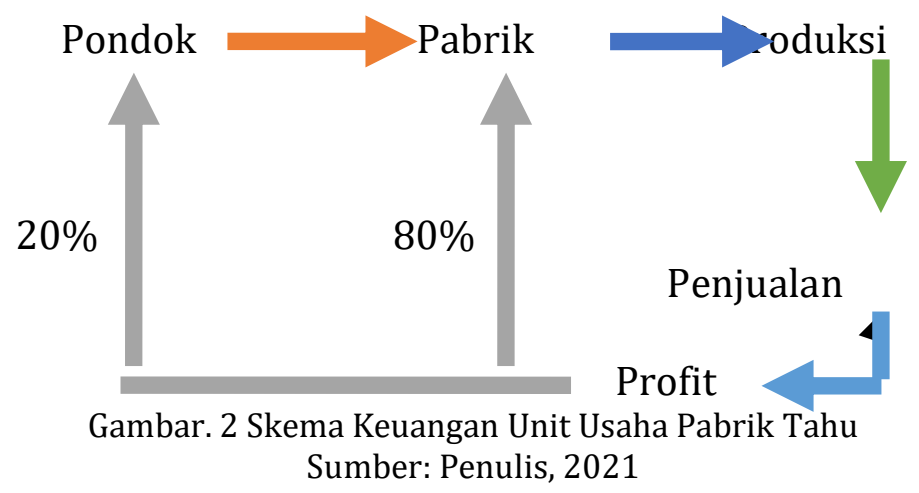

Data diatas menjelaskan jalannya profit dari mana kemana seperti yang sudah terbentuk melalui skema, pondok membangun pabrik untuk mengelola tahu yang dikonsumsi oleh pondok pesantren dan masyarakat serta profitnya dibagi kepada pondok pesantren sebesar $20 \%$ serta untuk pabrik $80 \%$ dengan keterlibatan penghasilan pabrik tahu sehingga dapat mengembangkan perekonomian pesantren. Setiap harinya Pabrik tahu memproduksi $60 \mathrm{~kg}$ perhari biji kedelai untuk dijadikan tahu dan hal tersebut bisa mencapai 40 papan disetiap papan berisi 100 biji tahu yang sudah dipotong kotak kotak perkotak dengan seharga Rp.17.000 per papan. Setiap harinya yang membutuhkan biaya kurang lebih Rp.370.000 untuk biaya membeli bahan bahan apa saja yang dibutuhkan untuk pembuatan tahu, tahu juga melakukan inovasi supaya berwarna seperti tahu susu, tahu geprek, tahu kribo sehingga tidak membosankan konsumen. Omset yang didapatkan perbulannya kurang lebih dari Rp.2.000.000 sampai Rp.4.000.000 sehingga kondisi keuangan pabrik tahu stabil. Disetiap bisnis pasti ada rugi dan untungnya dan hal tersebut harus ada laporannya karena laporan laba rugi itu merupakan suatu laporan yang menunjukkan kinerja keuangan unit usaha pada periode tertentu.

Laporan laba rugi adalah suatau laporan utama akuntan dalam mengukur kinerja ekonomi suatu usaha, yaitu pendapatan dikurangi dengan biaya biaya selama periode akuntansi tertentu. Dalam hal tersebut pernah dirasakan oleh unit usaha pabrik tahu $\mathrm{Al}$ Mashduqiah yang mana pendapatannya menurun dari hari biasanya diakibatkan dengan kenaikan kedelai, sedangkan harga produk tidak bisa dinaikkan karena konsumen yang sudah tau harga awalnya sehingga kanit (kepala unit) dan bagian koppontren sebagai pengelola keuangannya mencari cara bagaimana sekiranya tidak ada yang dirugikan satu sama lain, setelah kebijakan ditetapkan sehingga tahu ditipiskan sedikit sehingga tidak ada yang merasa dirugikan, dan hal tersebut tidak mengkwatirkan perkembangan ekonomi pabrik tahu ataupun pondok pesantren karna masih banyak konsumen yang minat membeli produk tahu ini.

Dari pembahasan diatas sudah jelas bahwasanya kemandirian ekonomi pondok pesantren melalui unit usaha yang sudah didirikan didalam pondok pesantren. 


\section{KESIMPULAN}

Unit usaha yang dijalankan oleh pondok pesantren Al Mashduqiah baik itu MJ(Murah Jaya), Toko putra, Toko putri, Pabrik roti, Glosir, Konveksi, Wartel, dan juga pabrik tahu tentunya memberikan dampak yang baik bagi pesantren, kondisi ini mendorong pesantren pada sebuah kondisi yang mana pesantren menjadi lembaga yang mandiri tidak sepenuhnya bergantung pada pendanaan dari pemerintah maupun masyarakat. Peneliti beharap bahwa penelitian ini dapat dikembangkan kembali oleh para peneliti-peneliti selanjutnya dengan cara menambah ataupun mengurangi, bahkan mengkombinasikan dengan perkembangan ekonomi pesantren lain, sehingga berimplikasi positif terhadap kemajuan perekonomian pesantren di Indonesia.

\section{DAFTAR PUSTAKA}

Bahri, Samsul, 'Pemikiran KH. Abdurrahman Wahid Tentang Sistem Pendidikan Pesantren', EDUGAMA: Jurnal Kependidikan Dan Sosial Keagamaan, 4.1 (2018), 10136

Basit, Abdul, and Tika Widiastuti, 'MODEL PEMBERDAYAAN DAN KEMANDIRIAN EKONOMI DI PONDOK PESANTREN MAMBA'US SHOLIHIN GRESIK', Jurnal Ekonomi Syariah Teori Dan Terapan, 6.4 (2016), 1-23

Darul, Jurnal, and Ilmi Vol, 'DINAMIKA PERKEMBANGAN PONDOK PESANTREN DI INDONESIA Oleh: Zulhimma 1', 01.02 (2013), 165-81

George R. Terry, Dasar Dasar Manejemen, 2013 <https://repository.widyatama.ac.id/xmlui/bitstream/handle/123456789/6350/

Bab 2.pdf?sequence $=11>$

Mannan, Abdul, and Inayah Swasti Ratih, 'Penerapan Etika Bisnis Islam Dalam Usaha Mikro Mebel/UMKM', IZZI : Jurnal Ekonomi Islam, 1.2 (2021), 133-47

Muttaqien, Dadan, 'Sistem Pendidikan Pondok Pesantren (Sebuah Alternatif Mengatasi Kegagalan Sistem Pendidikan Barat)', JPI FIAI Jurusan Tarbiyah Volume V Tahun IV Agustus 1999, V (1999), 79-87

Nizar, Samsul H, Sejarah Pendidikan Islam (Menelusuri Sejarah Pendidikan Era Rasulullah Sampai Indonesia) (Jakarta: Prenada Media Gorup, 2011)

Pesantren, Pondok, and Nurrohman Al-burhany Purwakarta, 'Jurnal Comm-Edu', 20, 2019, 193-201

Pramintasari, T., and I. Fatmawati, 'Pengaruh Keyakinan Religius, Peran Sertifikasi Halal, Paparan Informasi, Dan Alasan Kesehatan Terhadap Kesadaran Masyarakat Pada Produk Makanan Halal', Jurnal Manajemen Bisnis, 8.1 (2017), 1-33

Prasidjo, S., \& Al, E, Profil Pesantren", Dalam Abudin Nata (Editor), Sejarah Pertumbuhan Dan Perkembangan Lembaga-Lembaga Pendidikan Islam Di Indonesia. (Jakarta: Grasindo, 2001)

Salam, Muhammad Aminul Khoiris, 'Perilaku Produksi Di Tengah Krisis Global Akibat Pandemi Covid-19 Dan Memanfaatkan Media Online Facebook Sebagai Alternatif Pasar', Ekonomi, Manajemen Dan Akuntansi ISSN: 1979-9888, 2020, 1-21 <http://eprints.umsida.ac.id/id/eprint/6834> 
Sukma, MRP, 'Lembaga Pendidikan Pembentukan Karakter', Al-Tadzkiyyah: Jurnal Pendidikan Islam, 8 (2015), 85-103

Syafe'i, Imam, 'PONDOK PESANTREN: Lembaga Pendidikan Pembentukan Karakter', Al$\begin{array}{lllll}\text { Tadzkiyyah: Jurnal Pendidikan Islam, } 8.1 & \text { (2017), } 61\end{array}$ <https://doi.org/10.24042/atjpi.v8i1.2097> 